\title{
RHEUMATIC COMPLAINTS AMONG WORKERS IN IRON FOUNDRIES
}

\author{
BY \\ R. E. H. PARTRIDGE, J. A. D. ANDERSON, M. A. McCARTHY, \\ AND J. J. R. DUTHIE \\ Arthritis and Rheumatism Council \\ Industrial Survey Unit, Northern General Hospital, Edinburgh
}

Surveys of the prevalence and social effects of rheumatic diseases in several industries carried out by the Arthritis and Rheumatism Council's Industrial Survey Unit have indicated that, although the prevalence of rheumatic complaints varies between occupations, this variation does not seem to be related to the physical effort of the work involved (Anderson and Duthie, 1963; Partridge, Anderson, McCarthy, and Duthie, 1965). However, significant differences do apparently exist between industries, as was shown by the difference in the prevalence of rheumatic complaints between coal miners and dockyard workers (Anderson and Duthie, 1963). To explore further the relationship between the prevalence and the social and economic effects of rheumatism, these surveys have been extended to other industries.

During the course of a pilot survey, it was noted that foundry workers had a higher complaint rate than other groups, although with the small numbers of men involved the significance of this difference was uncertain. For this reason a group of iron foundries was selected for more extended study. Iron foundries offered a selection of occupations demanding varying degrees of physical effort generally performed under difficult and changeable environmental conditicns.

\section{Background and Method}

Six iron foundries each employing more than 100 men agreed to co-operate in the survey, one in Cheshire (Stockport) and five in the Falkirk district of Scotland.

In the making of finished products, the raw and partly finished materials were handled by men in a number of occupations. A variety of cast-iron objects from gas rings to drain pipes, manhole covers, and pillar boxes, were produced both by traditional methods and by more mechanized means on conveyor belts. In four factories, the development of light industry had made available for study a number of men concerned in the cutting and assembly of sheet steel and aluminium in the manufacture of electric fires, gas cookers, and similar goods. Thus both heavy and light industry were represented in these foundries.

Seven occupational groups were examined in detail.

(1) Iron moulders (floor moulders) cast iron by the traditional method of pouring the molten metal around a hard sand core in a heavy metal box packed with prepared sand. The work was performed much of the time in a stooping position on the floor but also involved shovelling, kneeling, pounding, and heavy lifting. After casting, the majority of these men acted as their own box knockers (a heavy part of the work), but in some foundries this was done for them.

(2) Machine moulders produced similar cast-iron object on a conveyor belt system, each man or group of men being concerned with a particular phase of the manufacture. The work was heavy and repetitive but was essentially performed in an upright position.

(3) Sheet metal workers and iron fitters were responsible for cutting sheet metal into required shapes and fitting metal parts together. The physical effort required varied but was less than that required in iron moulding.

(4) Pattern makers performed the traditional craft of making patterns out of wood and metal in the required shape of the object to be cast. The work was generally light and heavy lifting was uncommon.

(5) Dressers and polishers used grindstones and buffs on the iron after it had been cast to produce the required degree of finish. The work was mostly performed in an upright position and was fairly strenuous although heavy lifting was not common.

(6) Labourers performed a number of unskilled tasks around the foundry which varied considerably in physical effort.

(7) Fusers, iron-casters, and furnacemen were grouped together because of the common factor of the hot environment in which they worked and their frequent exposure to radiant heat.

A group of miscellaneous employees, including core makers, foremen, engineers, and painters was taken 
together for purposes of analysis, each occupational group being too small to consider separately.

Environmental conditions in the foundries were changeable. During the winter the moulding and dressing shops were often very cold in the morning and warmed up later in the day during the pouring of molten metal. Fitting shops varied from foundry to foundry. The men employed in pattern-making generally worked in warm, stable conditions.

The survey was limited to those employees actively concerned in the production of metal parts and finished products; transport workers, clerical workers, and others on the administrative staff were specifically excluded. The nominal roll of each foundry was obtained before beginning the survey. Permission to interview 100 per cent. of the employees was obtained at two foundries. In others a random sample of 50 per cent. of the nominal roll was obtained. For technical reasons it was possible to interview machine moulders at only two foundries, and at the Stockport foundry the sample was taken of men over the age of 35 . Elsewhere all employees over the age of 15 were included.

Each individual in the sample was asked to attend for an interview and brief medical examination, at which time a questionnaire was completed. The interview was conducted and the diagnoses made in the way described by Anderson, Duthie, and Moody (1962). No particular effort was made to limit the diagnostic labels to one per man as it was felt that common diseases would be unlikely to be mutually exclusive. Those who had rheumatic symptoms in the 12 months before the interview were designated "positives"; those who had symptoms at some other time in their working lives were classed as "intermediates"; the remainder who denied rheumatic symptoms at any time were classed as "negatives". Information was also collected about sickness absence in the past, functional capacity, and changes of occupation.

A group of positives and control negatives, matched for age and occupation, was referred to the medical social worker for interview to assess in greater detail their social background. For this interview, men classified as positives were selected with whom it was possible to match a negative control for age and occupation.
In addition to the social questionnaire, each individual of the selected group of positives and his matched negative were asked to complete the Maudsley Personality Inventory (Eysenck, 1959). A measure of two personality dimensions, Neuroticism or Emotionality (N Scale) and Extroversion (E Scale), was made, and these were related to other findings in the social survey. The interview was conducted as previously described (Partridge and others, 1965).

\section{Statistical Significance}

Where comparison has been made between agestandardized ratios for rheumatic complaints or specific diseases affecting different occupational groups, the statistical test used is that applied to occupational mortality rates (Registrar General, 1958). Elsewhere the $\chi^{2}$ test has been used.

\section{Results}

In the six foundries taking part in the study there were 918 men who were asked to attend for interview and of these $858(93.0$ per cent.) were seen and examined. The acceptance rate ranged from 90.2 to $96 \cdot 3$ per cent.

\section{Prevalence of Rheumatic Symptoms}

The prevalence of rheumatic complaints for a men by age is shown in Table $I . \quad 353$ men $(41 \cdot 1$ peD cent.) were classed as positives, 137 (16.0 per cent.) as intermediates, and $368(42.9$ per cent.) as negatives. 185 men $(21.6$ per cent.) were complaining of rheumatic symptoms at the time of interview. There was a clear positive correlation between age and recent symptoms. This relationship between age and complaint rate was taken into account when the prevalence of symptoms in the different foundry occupations was considered (Table II, opposite).

In this Table the Standardized Complaint Ratio

TABLE I

PREVALENCE OF RHEUMATIC COMPLAINTS

\begin{tabular}{|c|c|c|c|c|c|c|c|}
\hline \multirow{2}{*}{$\begin{array}{c}\text { Age } \\
\text { (years) }\end{array}$} & \multicolumn{2}{|c|}{ Positives } & \multicolumn{2}{|c|}{ Intermediates } & \multicolumn{2}{|c|}{ Negatives } & \multirow{2}{*}{$\begin{array}{c}\text { Total } \\
\text { Interviewed } \\
\text { (100 per cent.) }\end{array}$} \\
\hline & No. & Per cent. & No. & Per cent. & No. & Per cent. & \\
\hline $15-$ & 21 & $21 \cdot 9$ & 6 & $6 \cdot 2$ & 69 & $71 \cdot 9$ & 96 \\
\hline $25-$ & 41 & $32 \cdot 8$ & 23 & $18 \cdot 4$ & 61 & $48 \cdot 8$ & 125 \\
\hline $35-$ & 87 & $43 \cdot 3$ & 29 & $14 \cdot 4$ & 85 & $42 \cdot 3$ & 201 \\
\hline $45-$ & 92 & $44 \cdot 0$ & 33 & $15 \cdot 8$ & 84 & $40 \cdot 2$ & 209 \\
\hline $55-$ & 95 & $49 \cdot 7$ & 40 & $20 \cdot 5$ & 60 & $30 \cdot 8$ & 195 \\
\hline $65-$ & 17 & $53 \cdot 1$ & 6 & $18 \cdot 8$ & 9 & $28 \cdot 1$ & 32 \\
\hline All $15+$ & 353 & $41 \cdot 1$ & 137 & $16 \cdot 0$ & 368 & $42 \cdot 9$ & 858 \\
\hline
\end{tabular}


TABLE II

RHEUMATIC COMPLAINTS IN DIFFERENT OCCUPATIONS

(Standardized Ratios)

\begin{tabular}{|c|c|c|c|c|}
\hline Occupation & $\begin{array}{l}\text { Observed No. } \\
\text { of Positives }\end{array}$ & $\begin{array}{l}\text { Expected No. } \\
\text { of Positives }\end{array}$ & $\begin{array}{l}\text { Standardized } \\
\text { Complaint Ratio* }\end{array}$ & $\begin{array}{l}\text { Number of Workers } \\
\text { Interviewed }\end{array}$ \\
\hline Floor Moulders & 104 & $67 \cdot 8$ & $153 \cdot 3$ & 169 \\
\hline Furnacemen, Casters, Fusers & 17 & $16 \cdot 3$ & $104 \cdot 6$ & 39 \\
\hline Machine Moulders & 25 & $25 \cdot 9$ & $96 \cdot 6$ & 72 \\
\hline Labourers & 72 & $76 \cdot 4$ & $94 \cdot 3$ & 170 \\
\hline Fitters, Sheet Metal Workers & 42 & $52 \cdot 3$ & $80 \cdot 3$ & 134 \\
\hline Pattern Makers & 19 & $24 \cdot 6$ & $77 \cdot 2$ & 63 \\
\hline Dressers, Polishers & 29 & $38 \cdot 3$ & $75 \cdot 7$ & 90 \\
\hline All Other Occupations & 45 & $51 \cdot 5$ & $87 \cdot 4$ & 121 \\
\hline Total & 353 & $353 \cdot 1$ & $100 \cdot 0$ & 858 \\
\hline
\end{tabular}

*For definition see text

(SCR) for each occupation has been obtained from the fraction:

$$
\frac{\text { Observed No. of Positives }}{\text { Expected No. of Positives }} \times 100 \text {. }
$$

The expected number of positives was calculated by applying the complaint rates for the specific age groups in Table $I$ to the numbers in each occupation using the same age distribution.

Floor moulders $(\mathrm{SCR}=153 \cdot 3)$ had a much higher complaint ratio than other workers in the foundry $(P<0.001)$. Furnacemen, machine moulders, and labourers had complaint ratios near the mean; fitters, pattern makers, and dressers had low ratios. The difference between dressers with the lowest ratio (SCR $=75 \cdot 7)$ and other workers in the foundry was not significant $(0 \cdot 1>\mathrm{P}>0.05)$.

The prevalence of rheumatic complaints by decade for floor moulders and other foundry workers is given in Table III, where it will be seen that the complaint rate for floor moulders is much higher in every age group. 36 men (10.2 per cent.) of the total 353 positives described their complaints as fairly trivial; twenty out of 169 floor moulders (11.8 per cent.) had trivial complaints and were similar to the other foundry workers in this respect.

\section{Diagnosis}

The diagnoses made on clinical examination of positives and intermediates are shown in Table
IV (overleaf). Rheumatoid arthritis was diagnosed in twelve cases (1.4 per cent. of workers). An additional ten men $(1 \cdot 2$ per cent.) gave a history of incapacitating polyarthritis earlier in their lives that had left no clinically obvious damage. Osteoarthrosis (with an overall prevalence of 12 per cent.) affected few men under the age of 45 but there was a clear increase in prevalence in subsequent decades, with 25.5 per cent. of men over the age of 55 affected.

A history of neck and nerve root pain suggestive of cervical disk disease was obtained in ten men $(1 \cdot 2$ per cent.), five of whom also had lumbar disk disease. Vague aches and pains of neck and shoulder girdle were noted by fifty men $(5 \cdot 8$ per cent.).

Lumbar disk disease was diagnosed in 120 men (14.0 per cent.). In addition, there were another 155 men (18.1 per cent.) who had complaints of back pain at some time during their lives, but in whom a characteristic history of radiation of pain from a nerve root was absent. Combined together, the prevalence of all back complaints rose steadily with age up to the 35 to 44 age group. A drop in prevalence in the next decade was followed by a considerable increase in back complaints in those over 55. Other undetermined pains, mostly in the limbs, were recorded much less in those over the age of 55 ( 4.8 per cent.), probably because clinical signs

TABLE III

PERCENTAGE PREVALENCE OF RHEUMATIC COMPLAINTS IN FLOOR MOULDERS AND OTHERS

\begin{tabular}{l|c|c|c|c|r|r}
\hline \multirow{2}{*}{ Occupation } & \multicolumn{2}{c}{ Age (yrs) } \\
\cline { 2 - 6 } & $15-$ & $25-$ & $35-$ & $45-$ & $55-$ & All 15+ \\
\hline Floor Moulders & $44 \cdot 0$ & $59 \cdot 1$ & $68 \cdot 4$ & $59 \cdot 6$ & $71 \cdot 9$ \\
\hline Other Foundry Workers & $14 \cdot 0$ & $27 \cdot 2$ & $37 \cdot 4$ & $38 \cdot 8$ & $45 \cdot 6$ & $36 \cdot 1$ \\
\hline
\end{tabular}




\begin{tabular}{|c|c|c|c|c|c|c|c|c|}
\hline \multirow{2}{*}{\multicolumn{3}{|c|}{ Diagnosis }} & \multicolumn{6}{|c|}{ Age (yrs) } \\
\hline & & & $15-$ & $25-$ & $35-$ & $45-$ & $55-$ & All $15+$ \\
\hline \multirow{2}{*}{\multicolumn{2}{|c|}{ Rheumatoid Arthritis }} & Number & 1 & 0 & 1 & 6 & 4 & 12 \\
\hline & & Per cent. & $1 \cdot 1$ & $0 \cdot 0$ & $0 \cdot 5$ & $2 \cdot 9$ & $1 \cdot 8$ & $1 \cdot 4$ \\
\hline \multirow{2}{*}{\multicolumn{2}{|c|}{ Osteo-Arthrosis }} & Number & 0 & 3 & 8 & 27 & 65 & 103 \\
\hline & & Per cent. & $0 \cdot 0$ & $2 \cdot 4$ & $4 \cdot 0$ & $12 \cdot 9$ & $28 \cdot 6$ & $12 \cdot 0$ \\
\hline \multirow{2}{*}{\multicolumn{2}{|c|}{ Cervical Disk Disease }} & Number & 0 & 0 & 3 & 4 & 3 & 10 \\
\hline & & Per cent. & $0 \cdot 0$ & $0 \cdot 0$ & $1 \cdot 5$ & $1 \cdot 9$ & $1 \cdot 3$ & $1 \cdot 2$ \\
\hline \multirow{2}{*}{\multicolumn{2}{|c|}{ Lumbar Disk Disease }} & Number & 0 & 8 & 37 & 27 & 48 & 120 \\
\hline & & Per cent. & $0 \cdot 0$ & $6 \cdot 4$ & $18 \cdot 4$ & $12 \cdot 9$ & $21 \cdot 1$ & $14 \cdot 0$ \\
\hline \multirow{4}{*}{ Undetermined Pain } & \multirow{2}{*}{ Back } & Number & 18 & 25 & 36 & 28 & 48 & 155 \\
\hline & & Per cent. & $18 \cdot 7$ & $20 \cdot 0$ & $17 \cdot 9$ & $13 \cdot 4$ & $21 \cdot 1$ & $18 \cdot 1$ \\
\hline & \multirow{2}{*}{ Other } & Number & 6 & 22 & 29 & 37 & 11 & 105 \\
\hline & & Per cent. & $6 \cdot 3$ & $17 \cdot 6$ & $14 \cdot 4$ & $17 \cdot 7$ & $4 \cdot 8$ & $12 \cdot 2$ \\
\hline \multirow{2}{*}{\multicolumn{2}{|c|}{ Other Specified Rheumatic Conditions }} & Number & 3 & 8 & 11 & 13 & 16 & 51 \\
\hline & & Per cent. & $3 \cdot 1$ & $7 \cdot 2$ & $5 \cdot 5$ & $6 \cdot 2$ & $7 \cdot 0$ & $5 \cdot 9$ \\
\hline \multirow{2}{*}{\multicolumn{2}{|c|}{ All Rheumatic Complaints }} & Number & 27 & 64 & 116 & 125 & 158 & 490 \\
\hline & & Per cent. & $28 \cdot 1$ & $51 \cdot 2$ & $57 \cdot 7$ & $59 \cdot 8$ & $69 \cdot 6$ & $57 \cdot 1$ \\
\hline \multirow{2}{*}{\multicolumn{2}{|c|}{ No Symptoms }} & Number & 69 & 61 & 85 & 84 & 69 & 368 \\
\hline & & Per cent. & $71 \cdot 9$ & $48 \cdot 8$ & $42 \cdot 3$ & $40 \cdot 2$ & $30 \cdot 4$ & $42 \cdot 9$ \\
\hline \multicolumn{3}{|c|}{ Total Interviewed (on which percentages are based) } & 96 & 125 & 201 & 209 & 227 & 858 \\
\hline \multicolumn{3}{|l|}{ Double Diagnosis } & 1 & 2 & 8 & 16 & 35 & 61 \\
\hline
\end{tabular}

of degenerative disease became more obvious to the observer.

A history of other rheumatic conditions was obtained on 51 occasions (including the ten instances of polyarthritis above). "Beat" knee or pre-patellar bursitis predominantly affected floor moulders who accounted for fourteen out of the nineteen cases diagnosed $(8 \cdot 3$ per cent. of floor moulders). The incidence in floor moulders was probably higher than stated, as the condition was noted more frequently in the younger men, suggesting that the memory of the older men in this respect was faulty.

Ankylosing spondylitis was diagnosed on two occasions $(0 \cdot 2$ per cent.) and there was one case of gout.

A double diagnosis was made 61 times, 51 being in men over the age of 45 years.

It has already been demonstrated that floor moulders had a significantly higher complaint ratio than other workers in the foundry. Taking the age distribution into account, Table V (opposite) shows the standardized complaint ratios for disk disease and osteo-arthrosis in the different occupational groups. Floor moulders $(\mathrm{SCR}=177 \cdot 2)$ had a much higher prevalence of disk disease than other men $(\mathrm{P}<$ $0 \cdot 01)$, whereas dressers and polishers $(\mathrm{SCR}=23 \cdot 1)$ had a low ratio $(P<0.001)$. When the calculations are repeated for disk disease and backache of uncertain origin combined, the order of the standardized complaint ratios remains virtually unaltered and the significance of the highest and lowest ratios are unchanged.

The standardized complaint ratios for osteoarthrosis show no significant difference between one occupation and another.

From the histories taken it appeared that the initial incidence of back complaints of all types reached a peak around the age of 40 . The age at onset tended to occur earlier in floor moulders and machine moulders, 50 per cent. of back complaints in these groups developing before the age of 30 years. 
TABLE V

OCCUPATIONAL PREVALENCE OF LUMBAR DISK DISEASE AND OSTEO-ARTHROSIS Standardized Complaint Ratio (SCR)

\begin{tabular}{|c|c|c|c|c|c|c|}
\hline \multirow{2}{*}{ Occupation } & \multicolumn{3}{|c|}{ Lumbar Disk Disease } & \multicolumn{3}{|c|}{ Osteo-arthrosis } \\
\hline & $\begin{array}{c}\text { Observed } \\
\text { No. of } \\
\text { Positives }\end{array}$ & $\begin{array}{c}\text { Expected } \\
\text { No. of } \\
\text { Positives }\end{array}$ & SCR & $\begin{array}{c}\text { Observed } \\
\text { No. of } \\
\text { Positives }\end{array}$ & $\begin{array}{c}\text { Expected } \\
\text { No. of } \\
\text { Positives }\end{array}$ & SCR \\
\hline $\begin{array}{l}\text { 1. Floor Moulders } \\
\text { 2. Machine Moulders } \\
\text { 3. Labourers } \\
\text { 4. Furnacemen } \\
\text { 5. Fitters and Sheet Metal Workers } \\
\text { 6. Pattern Makers } \\
\text { 7. Dressers } \\
\text { 8. Miscellaneous }\end{array}$ & $\begin{array}{r}39 \\
7 \\
28 \\
5 \\
13 \\
5 \\
3 \\
20\end{array}$ & $\begin{array}{r}22 \\
7 \\
29 \\
6 \\
17 \\
8 \\
13 \\
18\end{array}$ & $\begin{array}{l}177 \cdot 2 \\
100 \cdot 0 \\
96 \cdot 5 \\
83 \cdot 4 \\
76 \cdot 4 \\
62 \cdot 5 \\
23 \cdot 1 \\
111 \cdot 1\end{array}$ & $\begin{array}{r}22 \\
3 \\
35 \\
4 \\
10 \\
6 \\
13 \\
10\end{array}$ & $\begin{array}{r}18 \\
3 \\
30 \\
4 \\
13 \\
7 \\
12 \\
16\end{array}$ & $\begin{array}{r}122 \cdot 2 \\
100 \cdot 0 \\
116 \cdot 7 \\
100 \cdot 0 \\
76 \cdot 9 \\
85 \cdot 7 \\
108 \cdot 3 \\
62 \cdot 5\end{array}$ \\
\hline All Men & 120 & 120 & $100 \cdot 0$ & 103 & 103 & $100 \cdot 0$ \\
\hline
\end{tabular}

\section{Effect on Working Capacity}

The functional capacity of every man giving a history of rheumatism was graded (Table VI) and in this context was related to his ability to do his work efficiently. There were 83 men $(9 \cdot 7$ per cent.) who had some functional limitation. There was a marked increase of disability over the age of 45 , when 62 men out of 204 positives (30.2 per cent.) had some functional limitation compared with 21 men out of 149 between 15 and 45 years (14.1 per cent.) $\left(\chi^{2}=11.8 ; \mathrm{P}<0.001\right)$.

\section{Sickness Absence (Table VII)}

Total sickness absence claimed by the men during the year before interview was 1,662 weeks (193.7

TABLE VI

FUNCTIONAL GRADING

\begin{tabular}{|c|c|c|c|c|c|c|c|c|}
\hline \multirow{2}{*}{\multicolumn{3}{|c|}{ Functional Grading }} & \multicolumn{6}{|c|}{ Age (yrs) } \\
\hline & & & $15-$ & $25-$ & $35-$ & $45-$ & $55-$ & All $15+$ \\
\hline \multicolumn{2}{|c|}{ Negatives and Intermediates } & $\begin{array}{l}\text { Number } \\
\text { Per cent. }\end{array}$ & $\begin{array}{l}75 \\
78 \cdot 1\end{array}$ & $\begin{array}{l}84 \\
67 \cdot 2\end{array}$ & $\begin{array}{c}114 \\
56 \cdot 7\end{array}$ & $\begin{array}{l}117 \\
56 \cdot 0\end{array}$ & $\begin{array}{l}115 \\
50.7\end{array}$ & $\begin{array}{l}505 \\
58.9\end{array}$ \\
\hline \multirow{3}{*}{ Positives } & No Limitation & $\begin{array}{l}\text { Number } \\
\text { Per cent. }\end{array}$ & $\begin{array}{l}20 \\
20 \cdot 9\end{array}$ & $\begin{array}{l}38 \\
30 \cdot 4\end{array}$ & $\begin{array}{l}70 \\
34 \cdot 8\end{array}$ & $\begin{array}{l}71 \\
33 \cdot 9\end{array}$ & $\begin{array}{l}71 \\
31 \cdot 3\end{array}$ & $\begin{array}{l}270 \\
31 \cdot 4\end{array}$ \\
\hline & Slight Disability & $\begin{array}{l}\text { Number } \\
\text { Per cent. }\end{array}$ & $1 \cdot 0$ & $\begin{array}{l}3 \\
2 \cdot 4\end{array}$ & $\begin{array}{l}15 \\
7 \cdot 5\end{array}$ & $\begin{array}{l}19 \\
9 \cdot 1\end{array}$ & $\begin{array}{l}29 \\
12 \cdot 7\end{array}$ & $\begin{array}{l}67 \\
7 \cdot 8\end{array}$ \\
\hline & $\begin{array}{l}\text { Moderate or } \\
\text { Severe Disability }\end{array}$ & $\begin{array}{l}\text { Number } \\
\text { Per cent. }\end{array}$ & - & 二 & $\stackrel{2}{1} \cdot 0$ & $\stackrel{2}{1 \cdot 0}$ & 12 & 16 \\
\hline \multicolumn{3}{|c|}{ Total Interviewed (on which percentage is based) } & 96 & 125 & 201 & 209 & 227 & 858 \\
\hline
\end{tabular}

TABLE VII

SICKNESS ABSENCE IN POSITIVES AND OTHERS

\begin{tabular}{|c|c|c|c|c|c|c|c|c|}
\hline & \multirow{2}{*}{\multicolumn{2}{|c|}{ Sickness absence }} & \multicolumn{6}{|c|}{ Age (yrs) } \\
\hline & & & $15-$ & $25-$ & $35-$ & $45-$ & $55-$ & All $15+$ \\
\hline \multirow{3}{*}{ Positives } & Rheumatic & $\begin{array}{l}\text { Weeks off in year } \\
\text { Rate per cent. }\end{array}$ & $\begin{array}{l}12 \\
57 \cdot 1\end{array}$ & $\begin{array}{c}54 \\
131 \cdot 5\end{array}$ & $\begin{array}{l}135 \\
155 \cdot 2\end{array}$ & $\begin{array}{l}111 \\
120 \cdot 7\end{array}$ & $\begin{array}{l}68 \\
60 \cdot 7\end{array}$ & $\begin{array}{l}380 \\
107 \cdot 6\end{array}$ \\
\hline & $\begin{array}{l}\text { Non Rheumatic } \\
\text { Illness }\end{array}$ & $\begin{array}{l}\text { Weeks off in year } \\
\text { Rate per cent. }\end{array}$ & $\begin{array}{l}24 \\
114 \cdot 2\end{array}$ & $\begin{array}{l}55 \\
134 \cdot 1\end{array}$ & $\begin{array}{l}124 \\
142 \cdot 6\end{array}$ & $\begin{array}{l}106 \\
115 \cdot 2\end{array}$ & $\begin{array}{l}314 \\
280 \cdot 4\end{array}$ & $\begin{array}{l}623 \\
176 \cdot 5\end{array}$ \\
\hline & \multicolumn{2}{|c|}{ No of Men Interviewed } & 21 & 41 & 87 & 92 & 112 & 353 \\
\hline \multirow{2}{*}{$\begin{array}{l}\text { Intermediates } \\
\text { and Negatives }\end{array}$} & $\begin{array}{l}\text { Non Rheumatic } \\
\text { Illness }\end{array}$ & $\begin{array}{l}\text { Weeks off in year } \\
\text { Rate per cent. }\end{array}$ & $\begin{array}{l}116 \\
154 \cdot 7\end{array}$ & $\begin{array}{c}87 \\
103 \cdot 6\end{array}$ & $\begin{array}{l}92 \\
80 \cdot 7\end{array}$ & $\begin{array}{l}207 \\
176 \cdot 7\end{array}$ & $\begin{array}{l}157 \\
136 \cdot 5\end{array}$ & $\begin{array}{l}659 \\
130 \cdot 5\end{array}$ \\
\hline & \multicolumn{2}{|c|}{ No. of Men Interviewed } & 75 & 84 & 114 & 117 & 115 & 505 \\
\hline \multirow[t]{2}{*}{ All Men } & All Illnesses & $\begin{array}{l}\text { Weeks off in year } \\
\text { Rate per cent. }\end{array}$ & $\begin{array}{l}152 \\
158 \cdot 3\end{array}$ & $\begin{array}{l}196 \\
156 \cdot 8\end{array}$ & $\begin{array}{l}351 \\
174 \cdot 6\end{array}$ & $\begin{array}{l}424 \\
202 \cdot 9\end{array}$ & $\begin{array}{l}539 \\
237 \cdot 4\end{array}$ & $\begin{array}{l}1,662 \\
193 \cdot 7\end{array}$ \\
\hline & \multicolumn{2}{|c|}{ No. of Men Interviewed } & 96 & 125 & 201 & 209 & 227 & 858 \\
\hline
\end{tabular}


weeks per 100 men); of these, 380 weeks $(22 \cdot 9$ per cent.) were claimed to be due to rheumatic complaints ( $44 \cdot 3$ weeks per 100 men). Sickness absence from non-rheumatic causes was higher in the rheumatic positives than in the others. The difference in rate fluctuated considerably in successive decades and the contribution of positives over the age of 55 largely accounted for the significant difference $\left(\chi^{2}=58.3 ; \mathrm{P}<0.001\right.$, on the basis of a 50 -week working year) between the positive group and others in this respect. $37 \cdot 4$ per cent. of sickness absence among positives was due to rheumatism and the annual rate in the middle decades, 25-54, was very similar to absence from non-rheumatic causes. From all causes, rheumatic positives had a much higher rate of sickness absence $(284 \cdot 1$ weeks per 100 men) than others in the foundry $(130.5$ weeks per 100 men).

The relative importance of individual rheumatic complaints in causing loss of employment is shown in Table VIII. Back pain, due either to lumbar disk disease or to less well defined causes was responsible for 252 weeks of absence $(66 \cdot 3$ per cent. of rheumatic sickness absence). Other specific rheumatic diseases, including osteo-arthrosis, accounted for $24 \cdot 2$ per cent. of rheumatic sickness absence and other vague pains mainly affecting the limbs were responsible for the rest.

The highest rate of sickness absence from rheumatism in the foundry occurred in furnacemen, labour- ers, and floor moulders (Table IX). Together, these men had an annual rheumatic absence rate of 64.8 weeks per 100 men compared with $28 \cdot 1$ weeks per 100 men for the others. The standardized absence ratio (SAR) was calculated in a similar way to that used for prevalence of rheumatic symptoms, taking the overall rheumatic sickness absence for each age group and applying it to individual occupations using the same age distribution. This has exaggerated the differences between occupations with respect to each other, although the order in terms of increasing rate of absence remains unchanged. Two men, a furnaceman with 40 weeks of absence in the previous year and a labourer with 30 weeks, have exaggerated the standardized ratios in this Table. The proportion of men in each occupation who were absent in the year is probably a better index of occupational differences.

Of the 75 men $(8 \cdot 7$ per cent. of the labour force) who were off work because of rheumatic complaints in the previous year, nineteen $(2 \cdot 2$ per cent.) were off for 6 weeks or more.

In the Scottish foundries, 757 men were asked if they had lost work from rheumatic complaints at any other time in their working life; 221 men (29.2 per cent.) had done so, the proportion rising to 41.6 per cent. in the over-55 age group. Therg were 83 men ( 11.0 per cent.) who had lost more than 6 weeks work, including 25 men ( 3.3 per cent.) whe had lost more than 25 weeks. The number of floor moulders who had ever been off work with

TABLE VIII

RELATIVE IMPORTANCE OF RHEUMATIC DISEASE CAUSING LOSS OF EMPLOYMENT

\begin{tabular}{|c|c|c|c|c|c|c|}
\hline Diagnosis & & & $\begin{array}{l}\text { Weeks off Work } \\
\text { in Past Year }\end{array}$ & $\begin{array}{c}\text { Percentage } \\
\text { of Total }\end{array}$ & $\begin{array}{l}\text { No. of Men } \\
\text { off Work }\end{array}$ & $\begin{array}{c}\text { Weeks off Work } \\
\text { per Man }\end{array}$ \\
\hline $\begin{array}{l}\text { Lumbar Disk Disease } \\
\text { Other Back Pain } \\
\text { Osteo-arthrosis } \\
\text { Specified Rheumatic } \\
\text { Other Vague Pain }\end{array}$ & $\begin{array}{l}\cdots \\
\cdots \\
\cdots \\
\cdots\end{array}$ & $\begin{array}{l}\cdots \\
\because \\
\cdots \\
\cdots\end{array}$ & $\begin{array}{r}186 \\
66 \\
54 \\
38 \\
36\end{array}$ & $\begin{array}{r}48 \cdot 9 \\
17 \cdot 4 \\
14 \cdot 2 \\
10 \cdot 0 \\
9 \cdot 5\end{array}$ & $\begin{array}{r}28 \\
22 \\
9 \\
8 \\
8\end{array}$ & $\begin{array}{l}6 \cdot 6 \\
3 \cdot 3 \\
6 \cdot 0 \\
4 \cdot 8 \\
4 \cdot 5\end{array}$ \\
\hline All Rheumatism & .. & .. & 380 & $100 \cdot 0$ & 75 & $5 \cdot 1$ \\
\hline
\end{tabular}

TABLE IX

SICKNESS ABSENCE FROM RHEUMATIC CAUSES, BY OCCUPATION

\begin{tabular}{|c|c|c|c|c|c|c|c|c|c|}
\hline \multicolumn{4}{|c|}{ Occupation } & $\begin{array}{c}\text { Total Weeks } \\
\text { Absent in } \\
\text { Year }\end{array}$ & $\begin{array}{l}\text { Rate per } 100 \\
\text { Interviewed }\end{array}$ & $\begin{array}{c}\text { Standardized } \\
\text { Ratio }\end{array}$ & $\begin{array}{c}\text { No. of Men } \\
\text { Absent in } \\
\text { Year }\end{array}$ & $\begin{array}{c}\text { Percentage } \\
\text { Absent }\end{array}$ & $\begin{array}{c}\text { No. of } \\
\text { Workers } \\
\text { Interviewed }\end{array}$ \\
\hline $\begin{array}{l}\text { Pattern Makers .. } \\
\text { Dressers . } \\
\text { Machine Moulders } \\
\text { Fitters and Sheet Metal } \\
\text { Floor Moulders .. } \\
\text { Labourers.. } \\
\text { Furnacemen, etc. } \\
\text { Other Occupations }\end{array}$ & $\begin{array}{l}\cdots \\
\ddot{1} \\
\ddot{w} \\
\cdots \\
\cdots\end{array}$ & $\begin{array}{l}\cdots \\
\cdots \\
\ddot{e r s} \\
\cdots \\
\cdots \\
\cdots\end{array}$ & $\begin{array}{l}\cdots \\
\cdots \\
\cdots \\
\cdots \\
\cdots \\
\cdots\end{array}$ & $\begin{array}{r}0 \\
3 \cdot 0 \\
20 \cdot 5 \\
47 \cdot 5 \\
74 \cdot 0 \\
114 \cdot 5 \\
56 \cdot 5 \\
64 \cdot 0\end{array}$ & $\begin{array}{r}0 \cdot 0 \\
3 \cdot 3 \\
27 \cdot 9 \\
35 \cdot 2 \\
43 \cdot 8 \\
67 \cdot 4 \\
140 \cdot 6 \\
52 \cdot 9\end{array}$ & $\begin{array}{r}0 \cdot 0 \\
7 \cdot 1 \\
62 \cdot 0 \\
83 \cdot 2 \\
98 \cdot 2 \\
157 \cdot 5 \\
280 \cdot 5 \\
106 \cdot 7\end{array}$ & $\begin{array}{r}0 \\
2 \\
6 \\
9 \\
20 \\
23 \\
4 \\
11\end{array}$ & $\begin{array}{r}0 \cdot 0 \\
2 \cdot 2 \\
8 \cdot 3 \\
6 \cdot 7 \\
11 \cdot 8 \\
13 \cdot 5 \\
10 \cdot 3 \\
8 \cdot 1\end{array}$ & $\begin{array}{r}63 \\
90 \\
72 \\
134 \\
169 \\
170 \\
39 \\
121\end{array}$ \\
\hline All Occupations .. & . & . & . & 380 & $44 \cdot 3$ & - & 75 & $8 \cdot 7$ & 858 \\
\hline
\end{tabular}


rheumatism was $65(41.5$ per cent.) compared with $156(25.4$ per cent.) of men in other occupations. When allowance was made for the effect of age on these results, the difference was significant $(P<0.05)$.

In the mechanized moulding plants, producing similar iron castings to floor moulders but by a different method, nine men ( 15.8 per cent.) had been off with rheumatism in previous years. Machine moulding was a young man's occupation in these foundries and there were few men over the age of 45. Comparison of men under the age of 45 in these two occupations, however, shows that even in the younger age group there was a difference; 28 out of 76 floor moulders (36.8 per cent.) and seven out of fifty machine moulders $(14.0$ per cent.) under 45 had been off with rheumatism in previous years $\left(\chi^{2}=6.75 ; P<0.01\right)$.

Sickness absence from non-rheumatic illness in the year before interview also varied between occupations. The highest rates were recorded by labourers, floor moulders, and machine moulders, about 40 per cent. of whom were absent during the year. Dressers, fitters, and pattern makers recorded lower rates. Comparison of absence rates for nonrheumatic illnesses and rheumatism in the various occupations showed a broad, although not absolute correlation between them, indicating that men in certain occupations (floor moulding, labouring) are likely to show higher absence rates than others, both for rheumatism and other diseases.

\section{Change of Occupation}

Change due to ill health of any sort is shown in Table X. 42 men ( 4.9 per cent. of the total) had ascribed this change of occupation to their rheumatic complaint; a further 68 men ( 7.9 per cent.) had changed their occupation because of other illnesses. A higher proportion of positives had changed their occupations from non-rheumatic illnesses than either negatives or intermediates, but the difference was not significant $\left(\chi^{2}=1 \cdot 70 ; 0 \cdot 2>P>0 \cdot 1\right)$.

Lumbar disk disease was the reason for change of occupation in 50 per cent. of men who changed because of rheumatism. Other rheumatic causes of job change were osteo-arthrosis (19.0 per cent.), backache (14.3 per cent.), specific rheumatic diseases $(9.5$ per cent.), and vague unclassified pains $(7 \cdot 2$ per cent.). These figures are very similar to those in Table IX showing the relative importance of rheumatic diseases in causing sickness absence. The previous occupation of forty of these men was known, and of them 27 (67.5 per cent.) were floor moulders, the majority of whom had become general labourers. Other occupations which were taken up were core making, packing, and paint spraying. A small proportion of floor moulders who took up new occupations were able to utilize part of their skill by becoming iron casters.

$78 \cdot 5$ per cent. of men who changed their occupations because of rheumatism had to accept a lower paid job; 59.6 per cent. of those changing because

TABLE X

CHANGE OF OCCUPATION FROM ILL HEALTH

\begin{tabular}{|c|c|c|c|c|c|c|c|c|}
\hline \multirow{2}{*}{ Group } & \multirow{2}{*}{\multicolumn{2}{|c|}{ Reason for Change of Job }} & \multicolumn{6}{|c|}{ (Age (yrs) } \\
\hline & & & $15-$ & $25-$ & $35-$ & $45-$ & $55-$ & All $15+$ \\
\hline \multirow{3}{*}{ Positive } & Rheumatism & $\begin{array}{l}\text { Number } \\
\text { Per cent. }\end{array}$ & $\begin{array}{l}0 \\
0.0\end{array}$ & $\begin{array}{l}3 \\
7 \cdot 3\end{array}$ & $\begin{array}{l}5 \\
5 \cdot 7\end{array}$ & $\begin{array}{l}9 \\
9 \cdot 8\end{array}$ & $\begin{array}{l}15 \\
13.4\end{array}$ & 32.1 \\
\hline & Other Illness & $\begin{array}{l}\text { Number } \\
\text { Per cent. }\end{array}$ & $\stackrel{3}{14 \cdot 3}$ & $\begin{array}{l}2 \\
0 \cdot 0\end{array}$ & $\begin{array}{l}5 \\
5 \cdot 7\end{array}$ & $\begin{array}{l}9 \\
8 \cdot 7\end{array}$ & $\begin{array}{l}15 \\
13 \cdot 4\end{array}$ & $\begin{array}{l}34 \\
9.6\end{array}$ \\
\hline & \multicolumn{2}{|c|}{ No. of Men in Group } & 21 & 41 & 87 & 92 & 112 & 353 \\
\hline \multirow{3}{*}{ Intermediate } & Rheumatism & $\begin{array}{l}\text { Number } \\
\text { Per cent. }\end{array}$ & $\begin{array}{c}1 \\
16 \cdot 7\end{array}$ & $\stackrel{0}{0.0}$ & $\stackrel{3}{10 \cdot 3}$ & $\begin{array}{c}2 \\
6 \cdot 1\end{array}$ & $\begin{array}{l}4 \\
8 \cdot 7\end{array}$ & $\begin{array}{l}10 \\
7 \cdot 8\end{array}$ \\
\hline & Other Illness & $\begin{array}{l}\text { Number } \\
\text { Per cent. }\end{array}$ & $\begin{array}{l}\mathbf{0} \\
\mathbf{0} .0\end{array}$ & $\begin{array}{l}0 \\
0.0\end{array}$ & $\stackrel{4}{13 \cdot 8}$ & ${ }^{1} \cdot 0$ & $\begin{array}{c}5 \\
10.9\end{array}$ & $\begin{array}{l}10 \\
7 \cdot 8\end{array}$ \\
\hline & \multicolumn{2}{|c|}{ No. of Men in Group } & 6 & 23 & 29 & 33 & 46 & 137 \\
\hline \multirow{2}{*}{ Negative } & Other Illness & $\begin{array}{l}\text { Number } \\
\text { Per cent. }\end{array}$ & $\begin{array}{l}2 \\
2 \cdot 9\end{array}$ & $\begin{array}{l}3 \\
4.9\end{array}$ & 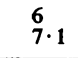 & $\stackrel{9}{10 \cdot 7}$ & $\begin{array}{l}5 \\
7 \cdot 2\end{array}$ & 25 \\
\hline & \multicolumn{2}{|c|}{ No. of Men in Group } & 69 & 61 & 85 & 84 & 69 & 368 \\
\hline \multirow{2}{*}{ All Men } & All Illnesses & $\begin{array}{l}\text { Number } \\
\text { Per cent. }\end{array}$ & $\begin{array}{l}6 \\
6 \cdot 3\end{array}$ & $\begin{array}{l}8 \\
6 \cdot 4\end{array}$ & $\begin{array}{l}23 \\
11 \cdot 4\end{array}$ & $\begin{array}{l}30 \\
14 \cdot 3\end{array}$ & $\begin{array}{l}44 \\
19 \cdot 4\end{array}$ & $\begin{array}{r}111 \\
12.9\end{array}$ \\
\hline & \multicolumn{2}{|c|}{ No. of Men in Group } & 96 & 125 & 201 & 209 & 227 & 858 \\
\hline
\end{tabular}


of other illnesses were likewise affected $\left(\chi^{2}=3 \cdot 23\right.$; $0.1>\mathrm{P}>0.05$ ) (Table XI). 156 men who had changed their occupations for reasons other than health within the previous 10 years were asked a similar question about financial gain or loss. Only 15.4 per cent. had taken a lower paid job; the majority (59.6 per cent.) had gained financially by the change. The difference between these men and those forced to change from ill health was highly significant $\left(\chi^{2}=85 \cdot 6 ; n=6 ; \mathrm{P}<0 \cdot 001\right)$.

\section{Results of Social Survey}

186 men were interviewed by the Medical Social Worker during the course of the survey: 93 positives and 93 negatives matched for age and occupation. The aims of the social survey and the type of questions used were those described by Partridge and others (1965). The diagnostic breakdown of the positive group was basically similar to the foundry as a whole. Marital status of the positive and negative groups was nearly equal.

\section{Other Complaints of Illness}

48 men of the positive group and 27 negatives were complaining of illnesses other than rheumatism at the time of interview; the difference between these two groups in this respect was significant $\left(x^{2}=8.94\right.$; $\mathbf{P}<0.01)$. Fifteen positives had multiple other complaints compared with only three negatives. Eighteen positives (19.4 per cent.) had complaints referable to the gastrointestinal tract compared with five negatives $(5.4$ per cent.); this difference was significant $\left(\chi^{2}=7 \cdot 15 ; P<0.02\right)$. The positives also had a greater number of complaints referable to the heart, chest, eyes, and other organs, but the differences were not significant.

\section{Effects of Illness in Previous Year}

The difference between positives and negatives regarding loss of work from non-rheumatic illnesses was not significant ( 35 positives, 30 negatives) $\left(\chi^{2}=\right.$ $0.38 ; 0.7>P>0.5)$. A further seventeen positives had lost work because of rheumatism; the difference between positives and negatives regarding the number of men off work from all illnesses was significant $\left(\chi^{2}=9.62 ; \mathrm{P}<0.005\right)$. Three of the positive group were downgraded at work because of illness and one had lost his job. Neither of these circumstances occurred in the negative group. 29 positives reported financial loss because of illness compared with seventeen in the negative group. The difference was due to the additional effect of rheumatic sickness absence, although statistically it was just below the level of significance $\left(\chi^{2}=3 \cdot 49\right.$; $0 \cdot 1>P>0.05)$. No effects of illness on social relationships with others were recorded in either group.

\section{Environmental Influences in Childhood}

Chronic illness in the early home environment (excluding the subject) occurred in relatives of 45 of the positive group and in thirty of the negative group $\left(\chi^{2}=4.38 ; \quad P<0.05\right)$. No differences between the groups were noted with respect to parental or other family influences.

\section{Present Environmental Influences}

No differences between the groups existed with regard to marital status, marital harmony, or housing. 45 of the positive group and 24 of the negative group claimed to share a house with another person suffering from chronic ill health. The differenco between the two groups was significant $\left(x^{2}=9 \cdot 22\right.$ $\mathbf{P}<0.01)$.

\section{Maudsley Personality Inventory (MPI)}

184 men were asked to complete the MPI. In eighteen instances more than ten questions in the inventory were left unanswered, and these men and their opposite matched pairs were discarded from subsequent analysis. The results of the neuroticism rating ( $\mathrm{N}$ Scale) and the extroversion rating (E Scale) are shown in Table XII. There were no significant differences between positive and negative groups with respect to mean values of either $\mathbf{N}$ or $\mathbf{E}$.

TABle XII

MPI SCORES (mean \pm SD)

\begin{tabular}{l|c|c|c}
\hline \multicolumn{1}{c|}{ Group } & No. of Men & N Scale & E Scale \\
\hline Positive & 74 & $20 \cdot C \pm 9 \cdot 8$ & $\begin{array}{c}25 \cdot 5 \pm 8 \cdot 4 \\
\text { Negative }\end{array}$ \\
\hline
\end{tabular}

TABLE XI

PERCENTAGE FINANCIAL CHANGE FOLLOWING CHANGE OF OCCUPATION

\begin{tabular}{|c|c|c|c|c|c|c|c|c|}
\hline \multicolumn{4}{|c|}{$\begin{array}{l}\text { Reason for Change } \\
\text { of Occupation }\end{array}$} & $\begin{array}{l}\text { Higher } \\
\text { Wages }\end{array}$ & $\begin{array}{l}\text { No } \\
\text { Change }\end{array}$ & $\begin{array}{l}\text { Lower } \\
\text { Wages }\end{array}$ & $\stackrel{\text { No }}{\text { Information }}$ & $\begin{array}{l}\text { No. of Men } \\
\text { in Group }\end{array}$ \\
\hline $\begin{array}{l}\text { Rheumatic Complaints } \\
\text { Non Rheumatic Illnesses } \\
\text { No Illness } \quad \text {. } \quad \text {.. }\end{array}$ & $\begin{array}{l}\cdots \\
\cdots\end{array}$ & $\begin{array}{l}\cdots \\
\cdots\end{array}$ & $\begin{array}{l}\cdots \\
\cdots\end{array}$ & $\begin{array}{l}14 \cdot 3 \\
18 \cdot 9 \\
59 \cdot 6\end{array}$ & $\begin{array}{r}2 \cdot 4 \\
13 \cdot 0 \\
20 \cdot 5\end{array}$ & $\begin{array}{l}78 \cdot 5 \\
59 \cdot 4 \\
15 \cdot 4\end{array}$ & $\begin{array}{l}4 \cdot 8 \\
8 \cdot 7 \\
4 \cdot 5\end{array}$ & $\begin{array}{r}42 \\
69 \\
156\end{array}$ \\
\hline
\end{tabular}


The relationship between duration of sickness absence from any cause and the MPI scores is shown in Table XIII. No significant differences exist either between positives and negatives, or between those who were off work and those who were not. Similarly, the MPI scores of men complaining of various non-rheumatic symptoms were not significantly different from those who did not (Table XIV).

\section{Discussion}

The present survey was undertaken as part of a general survey of industry to assess the prevalence and some of the social and economic effects of rheumatic complaints in the working population. Iron foundries visited in the survey were old and the factory areas where cast iron was produced were climatically variable depending upon the season and the time of day. Extremes of heat tended to be encountered in these areas, affecting moulders, furnacemen, and some labourers. Fitters, sheet metal workers, and pattern makers usually worked in more even conditions. Dressing shops were variable. but extremes of heat were absent.

A comparison of the rheumatic complaint rate of foundry workers with those of industries previously investigated by the Industrial Survey Unit is shown in Table XV. The SCRs in this Table were calculated for the five industries as described above, taking the age distribution of all 3,306 men into account. Foundry workers had a complaint rate just below the expected rate (SCR 98-1). The

TABLE XIII

RELATIONSHIP OF DURATION OF SICKNESS ABSENCE (ALL CAUSES) TO MPI SCORES (mean \pm S.D.)

\begin{tabular}{|c|c|c|c|c|c|}
\hline \multirow{2}{*}{ Scale } & \multirow{2}{*}{ Group } & \multicolumn{4}{|c|}{ Sickness Absence (wks) } \\
\hline & & $\mathbf{0}$ & 1 & 2 & 3 or More \\
\hline $\mathbf{N}$ & $\begin{array}{c}\text { Positive } \\
\text { Negative }\end{array}$ & $\begin{array}{l}20.6 \pm 10.3 \\
16.0 \pm 7.0\end{array}$ & $\begin{array}{l}24 \cdot 2 \pm 9 \cdot 2 \\
19 \cdot 8 \pm 8 \cdot 0\end{array}$ & $\begin{array}{l}21.9 \pm 8.2 \\
15.4 \pm 9.8\end{array}$ & $\begin{array}{l}17 \cdot 6 \pm 9 \cdot 8 \\
18 \cdot 3 \pm 8 \cdot 8\end{array}$ \\
\hline $\mathbf{E}$ & $\begin{array}{c}\text { Positive } \\
\text { Negative }\end{array}$ & $\begin{array}{l}26 \cdot 2 \pm 8 \cdot 5 \\
25 \cdot 7 \pm 9 \cdot 8\end{array}$ & $\begin{array}{l}26 \cdot 1 \pm 5 \cdot 7 \\
26 \cdot 8 \pm 6 \cdot 9\end{array}$ & $\begin{array}{l}25 \cdot 6 \pm 6 \cdot 1 \\
28 \cdot 0 \pm 6 \cdot 9\end{array}$ & $\begin{array}{l}23 \cdot 1 \pm 7 \cdot 3 \\
24 \cdot 9 \pm 7 \cdot 0\end{array}$ \\
\hline
\end{tabular}

TABLE XIV

RELATIONSHIP OF COMPLAINTS OF NON RHEUMATIC ILLNESS TO MPI SCORES (mean \pm S.D.)

\begin{tabular}{|c|c|c|c|c|}
\hline \multirow{2}{*}{ Scale } & \multirow{2}{*}{ Group } & \multicolumn{3}{|c|}{ Number of Non Rheumatic Complaints } \\
\hline & & $\mathbf{0}$ & 1 & 2 or More \\
\hline $\mathbf{N}$ & $\begin{array}{l}\text { Positive } \\
\text { Negative }\end{array}$ & $\begin{array}{l}20 \cdot 2 \pm 10 \cdot 8 \\
16 \cdot 1 \pm 9 \cdot 0\end{array}$ & $\begin{array}{l}18 \cdot 3 \pm 10 \cdot 6 \\
17 \cdot 5 \pm 9 \cdot 1\end{array}$ & $\begin{array}{c}24 \cdot 0 \pm 6 \cdot 4 \\
(18 \cdot 3 \pm 11 \cdot 1)^{*}\end{array}$ \\
\hline $\mathbf{E}$ & $\begin{array}{c}\text { Positive } \\
\text { Negative }\end{array}$ & $\begin{array}{l}26 \cdot 0 \pm 6.9 \\
26.9 \pm 8 \cdot 5\end{array}$ & $\begin{array}{l}24 \cdot 7 \pm 9 \cdot 8 \\
26 \cdot 3 \pm 5 \cdot 1\end{array}$ & $\begin{array}{l}25.8 \pm 5 \cdot 5 \\
(33 \cdot 0 \pm 6 \cdot 7)^{*}\end{array}$ \\
\hline
\end{tabular}

*Only 3 men in group

TABLE XV

COMPLAINT RATE IN FIVE INDUSTRIES

(Standardized Complaint Ratios (SCR))

\begin{tabular}{|c|c|c|c|c|c|c|c|c|}
\hline \multirow{2}{*}{\multicolumn{5}{|c|}{ Occupation }} & \multirow{3}{*}{$\begin{array}{c}\begin{array}{c}\text { No. of Workers } \\
\text { Interviewed }\end{array} \\
402\end{array}$} & \multirow{2}{*}{\multicolumn{2}{|c|}{ Number Positive }} & \multirow{2}{*}{$\begin{array}{l}\text { SCR } \\
117 \cdot 3\end{array}$} \\
\hline & & & & & & & & \\
\hline Coal Miners & $\ldots$ & . & $\ldots$ & $\ldots$ & & $\frac{\text { Observed }}{185}$ & $\begin{array}{c}\text { Expected } \\
157.6\end{array}$ & \\
\hline Brewery Workers & $\ldots$ & $\ldots$ & .. & . & 412 & 172 & $155 \cdot 2$ & $110 \cdot 8$ \\
\hline Electronic Engineeri & Wo & cers & $\ldots$ & .. & 212 & 76 & $71 \cdot 0$ & $107 \cdot 0$ \\
\hline Foundry Workers & $\ldots$ & $\ldots$ & . & . & 858 & 353 & $360 \cdot 0$ & $98 \cdot 1$ \\
\hline Dockyard Workers & $\ldots$ & $\ldots$ & . & . & 1,422 & 522 & $564 \cdot 8$ & $92 \cdot 4$ \\
\hline Total & $\ldots$ & $\ldots$ & $\ldots$ & .. & 3,306 & 1,308 & $1,308 \cdot 6$ & 100 \\
\hline
\end{tabular}


difference between foundry workers and all the other workers in respect of prevalence was not significant $(0 \cdot 8>\mathrm{P}>0 \cdot 7)$. Coal miners $(\mathrm{SCR}=117 \cdot 3)$ have a significantly higher complaint rate than foundry workers $(\mathrm{P}<0.05)$ but dockyard workers with a lower complaint rate $(\mathrm{SCR}=92.4)$ were not significantly different $(0.1>\mathbf{P}>0.05)$. Lawrence, Molyneux, and Dingwall-Fordyce (1966), in a survey of 299 iron foundry workers in Lancashire and Cheshire, found a history of rheumatic complaints in 63 per cent. of men over the age of 35 years, $26 \cdot 7$ per cent. having symptoms at the time of survey. They considered rheumatic complaints in foundry workers, both past and present, to be significantly less frequent than expected, using a random sample of men as a control. In the present survey, 399 men $(62.7$ per cent.) over 35 years of age had a history of rheumatism (positives and intermediates). The expected number, as determined by the complaint rate of all ISU survey males and corrected to the foundry workers' age distribution, was $409(0.7>\mathrm{P}>0.6)$. 164 men over 35 years old $(25 \cdot 8$ per cent.) were complaining of rheumatic symptoms at time of interview. The expected number was $136(\mathrm{P}<0.05)$. Thus, although foundry workers in this survey had a complaint rate similar to what was expected, a greater number of men were complaining at time of interview.

It was apparent that within the iron foundries there was a wide variation of complaint rate between occupations. Floor moulders had by far the highest complaint rate of any group within the industry, and the difference between this group and other workers was highly significant. This difference was present in all age groups and was particularly noticeable in the younger men. The difference in complaint rate was mostly due to a higher prevalence of lumbar disk disease and less well-defined backache among floor moulders compared with the rest of the foundry. Floor moulders also had a high prevalence of prepatellar bursitis. Although their rate for osteoarthrosis ( $\mathrm{SCR}=122 \cdot 2)$ was the highest in the foundry, it was not significantly different from other occupations.

Iron moulding by the traditional hand method is an occupation that can be classified as "heavy" in the sense of the physical effort demanded of a man. Other occupations in the foundry could also be "heavy", in particular, machine moulding. In each instance, the end product is the same, and the box filling, metal pouring, and the box breaking (knocking) demand similar muscle strength and effort. The significant difference in complaint rate between these two groups and in the complaint rate for disk disease can perhaps be equated with differences in method of working. Floor or hand moulding, as its name implies, is done predominantly at floor level; the successive stages of box filling, packing, casting, and knocking being done by the same man. The position of the box on the floor necessitates a stooping position for much of the working day. Filled boxes weighing $100-200$ pounds are lifted by hand from floor level, thus exposing the back to maximum stress. In machine moulding most of the heavy lifting is done from raised surfaces.

Troup (1965) has shown that, in lifting from ground level with the trunk horizontal, the intervertebral compression force will be not less than five times the combined weight of trunk, upper limbs, and the load lifted, depending upon the speed with which inertia is overcome and the acceleration. From this type of survey it is difficult to be sure of factors which initiate disk degeneration, but the repeated stress to which the lumbar spine of the floor moulders is exposed must presumably play a great part. Lawrence and others (1966) have shown a higher prevalence radiologically of severe disk degeneration of the lumbar spine but not of the dorsal spine in moulders than in other foundry workers.

Previous surveys (Anderson and Duthie, 1963 Partridge and others, 1965) have indicated thate rheumatic complaint rates do not appear to be related to the heaviness of the work involved. In a? study of weight lifters, Hult (1954) showed that the incidence of disk degeneration was no higher than in light workers. It is possible, however, that heavy work performed under conditions of mechanical stress, as in having to work in a stooped position, may be a factor in increasing the prevalence and severity of disk degeneration in the floor moulders studied in this survey.

The frequent kneeling involved in floor moulding may account for the high prevalence of pre-patellar bursitis in this group of men.

Rheumatoid arthritis was encountered in twelve cases (1.4 per cent. of workers). From the findings of Lawrence (1961), the expected number of men with rheumatoid arthritis would be about twenty. Of the ten men with transient polyarthritis, a few may have had rheumatic fever, but the others may fall into the category of benign polysynovitis (Lawrence and Bennett, 1960). Although the prevalence of transient incapacitating polyarthritis in the present survey was lower than the 5 per cent. of males quoted by these authors, it confirms the fact that the condition, whatever the cause, is not uncommon.

Rheumatic complaints as causes of incapacity for work were responsible for 380 weeks of sickness 
absence. The expected number of weeks (Table XVI), based upon the total for all survey males and corrected for age, was 343.7 weeks. Backache, including lumbar disk disease, was easily the most important cause of incapacity; $66 \cdot 3$ per cent. of rheumatic sickness absence was from these causes, a proportion that closely correlated with their importance in diagnosis ( 57 per cent. of complaints).

196 men (36.5 per cent.) out of 636 men over 35 years old in the Scottish foundries had been off work at some time during their working lives and sixty (11.2 per cent.) had lost 3 months or more from work. Lawrence and others (1966) gave a similar figure of 34.5 per cent. of men who had lost work from rheumatism at any time, but fewer foundry workers in their survey $(8.7$ per cent.) had been off for 3 months or more.

There was some correlation between sickness absence and heaviness of foundry work, but it was not as close as had been previously recorded in the dockyard (Anderson and Duthie, 1963). Pattern makers, with no rheumatic sickness absence, had the lightest job physically, but fitters, sheet metal workers, and furnacemen had higher rates than might be expected, considering the effort required in these occupations compared with the more strenuous occupations of floor moulding and machine moulding. Sickness absence from rheumatism may vary from year to year in an occupation (Partridge, 1966) and a better guide to the effect of rheumatism in an occupation may be gained from a study of sickness absence and the proportion of men involved extending over a number of years. It may be significant in this regard that floor moulders, 41.5 per cent. of whom had been off work with rheumatic complaints at some time, had the highest rate in the foundry.

There was a remarkably close observer agreement between the present study and that of Lawrence and others (1966) with regard to the prevalence of rheumatic complaints, the number of men complaining at time of interview, and the number of men off work from rheumatism in the iron foundries.
There was a difference in prevalence rates in the control groups used in these two surveys, from which the expected number of complaints in each case was obtained. In Lawrence's study, the rate was significantly higher in the control group; in this survey it was not. The present study does not, therefore, confirm the suggestion that the intermittent radiant heat to which foundry workers are exposed has any influence on the complaint rate. Indeed, the complaints present at time of interview and the number of weeks of incapacity in the previous year were higher than expected. Floor moulders and furnacemen, casters, and fusers, all of whom were exposed to radiant heat to a much greater degree than other foundrymen, had among the highest complaint and absence rates in the foundry.

The results recorded here confirm that changes of occupation ascribed to rheumatism occur in addition to those ascribed to other diseases. In addition, the fact that a man leaving a job for health reasons is usually forced to take lower paid employment, usually of an unskilled nature, demonstrates the overall disadvantage that rheumatic subjects suffer compared with the rest of the population. As might be expected, complaints referable to the lumbar spine were responsible for the major part (64.3 per cent.) of changes of occupation due to rheumatism. It was not possible to study men who had left the foundries altogether, but assuming that the industry employs as many of its disabled as it can, it was apparent that the occupational risk was greatest in floor moulders, and the majority of the men affected became general labourers. Opportunities for re-training in the area were not studied, but the selection of alternative occupations would be limited by Trade Union requirements.

Further study of the $\mathrm{N}$ and $\mathrm{E}$ Scales of the Maudsley Personality Inventory confirmed the original impression gained among workers in light industry (Partridge and others, 1965) that there was little personality difference between rheumatic

TABLE XVI

MALE SICKNESS ABSENCE FROM RHEUMATIC CAUSES IN FIVE INDUSTRIES

\begin{tabular}{|c|c|c|c|c|c|c|c|c|}
\hline \multirow{2}{*}{\multicolumn{5}{|c|}{ Occupation }} & \multirow{3}{*}{$\begin{array}{c}\begin{array}{c}\text { No. of Workers } \\
\text { Interviewed }\end{array} \\
402\end{array}$} & \multicolumn{2}{|c|}{ Total No. of Weeks Absence in Year } & \multirow{3}{*}{$\begin{array}{c}\begin{array}{c}\text { Standardized } \\
\text { Absence } \\
\text { Ratio }\end{array} \\
126 \cdot 3\end{array}$} \\
\hline & & & & & & \multirow{2}{*}{$\frac{\text { Observed }}{188}$} & \multirow{2}{*}{$\frac{\text { Expected }}{148 \cdot 8}$} & \\
\hline Coal Miners & $\ldots$ & . & . & .. & & & & \\
\hline Brewery Workers & $\ldots$ & $\ldots$ & $\ldots$ & $\ldots$ & 412 & 176 & $146 \cdot 1$ & $120 \cdot 5$ \\
\hline Fcundry Workers & $\cdots$ & . & $\ldots$ & . & 858 & 380 & $343 \cdot 7$ & $110 \cdot 5$ \\
\hline Dockyard Workers & . & . & $\ldots$ & .. & 1,422 & 482 & 5331 & $90 \cdot 4$ \\
\hline \multicolumn{3}{|c|}{ Electronic Engineering Workers } & $\ldots$ & . & 212 & 14 & $68 \cdot 2$ & $20 \cdot 5$ \\
\hline Total & $\ldots$ & .. & $\ldots$ & .. & 3,306 & 1,240 & $1,239 \cdot 9$ & 100 \\
\hline
\end{tabular}


positive and negative males, at least in the dimensions of neuroticism and extroversion as measured here. Whereas "psychogenic rheumatism" may be a real entity, there was no evidence in this survey to suggest that psychological factors had any significant bearing on complaint rates or sickness absence from rheumatic and other causes.

As in previous surveys, examination of environmental condition in positives and others was unrewarding. There was, however, an interesting aggregation of other diseases associated directly and indirectly with the positive group. Rheumatic positives tended to have greater sickness absence from other complaints and they also were complaining of a greater number of symptoms at time of interview. Examination of the $\mathrm{N}$ Scale scores of these men did not support the idea that they were more neurotic than the others. It is tempting to associate the increased amount of dyspeptic complaints in the positive group with self-medication with salicylates and other drugs, but no direct information is available on this point. The rheumatic positive subjects themselves gave the impression of being associated in both early and adult life with relatives suffering from a chronic or recurrent illness. Again there was no direct evidence to support these statements, which may simply reflect a heightened awareness for illness in a person himself suffering from a chronic illness such as a form of rheumatism.

\section{Summary}

(1) A survey of 858 male iron foundry workers over the age of 15 years was carried out to assess the social and economic importance of rheumatic complaints among them as part of a continuing study in industry.

(2) 42.9 per cent. had had complaints in the year before interview, a proportion similar to that expected.

(3) Lumbar back pain, including lumbar disk disease, was responsible for 57 per cent. of rheumatic complaints, $66 \cdot 3$ per cent. of rheumatic sickness absence, and $64 \cdot 3$ per cent. of change of occupation due to rheumatism.

(4) The foundry workers formed a heterogeneous population regarding complaint rate and sickness absence which varied between occupations.

(5) Floor moulders were a special group at high risk in the development of rheumatic complaints, particularly disk disease.

(6) There was no evidence that exposure to high levels of radiant heat in the foundry reduced complaint rate or sickness absence from rheumatism.

(7) The psychological factors that were studied in these workers appeared to have no relationship to the prevalence of rheumatic complaints, sickness absence, or the association of rheumatism with other complaints.

We wish to express our gratitude to the Arthritis and Rheumatism Council who are financing this project. We् are also grateful for the help and co-operation of the management and employees of Carron Company, Allie Ironfounders Limited, Smith and Welstood (Mfg) Ltd., Grange-Camelon Iron Co. Ltd., Jones and Campbell Ltd., and John Needham Ltd., and we should like to thank the representatives of the Amalgamated Union of Foundry Workers of Great Britain and Ireland, the Scottish Metal Workers Association, and the United Pattern Makers Association for their help and interest.

\section{REFERENCES}

Anderson, J. A. D., and Duthie, J. J. R. (1963). Ann. rheum. Dis., 22, 401 (Rheumatic complaints in dockyard workers).

,-- , and Moody, B. P. (1962). Ibid., 21, 342 (Social and economic effects of rheumatic diseases in a mining population).

Eysenck, H. J. (1959). "Manual of the Maudsley Personality Inventory". University of London Press, London.

Hult, L. (1954). Acta orthop. scand., Suppl. 17 (Cervical, dorsal, and lumbar spinal syndromes).

Lawrence, J. S. (1961). Ann. rheum. Dis., 20, 11 (Prevalance of rheumatoid arthritis).

- and Bennett, P. H. (1960). Ibid., 19, 20 (Benign polyarthritis).

- Molyneux, M. K., and Dingwall-Fordyce, I. (1966). Brit. J. industr. Med., 23, 42 (Rheumatism in foundry workers).

Partridge, R. E. H. (1966). " Annual Report of the Arthritis and Rheumatism Council for Research".

- Anderson, J. A. D., McCarthy, M. A., and Duthie, J. J. R. (1965). Ann. rheum. Dis., 24, 332 (Rheumatism in light industry).

Registrar General (1958). "Decennial Supplement England and Wales, 1951", Occupational Mortality, Part II, Volume I. Commentary.

Troup, J. D. G. (1965). Lancet, 1, 857 (Relation of lumbar spine disorders to heavy manual work and lifting). 
La fréquence des manifestations rhumatismales chez les fondeurs de fer

RÉSUMÉ

(1) On procéda à une enquête chez 858 fondeurs de fer, à partir de l'âge de 15 ans, pour déterminer l'importance sociale et économique des manifestations rhumatismales. Cette enquête fait partie d'une étude plus générale de ces manifestations dans l'industrie.

(2) Au cours de l'année précédant l'entrevue 42,9 pour cent d'entre eux avaient eu des symptômes, ce qui est le pourcentage attendu.

(3) Les lombalgies, y compris la maladie du disque lombaire, faisaient partie de 57 pour cent des manifestations rhumatismales, de 66,3 pour cent des absences pour maladie rhumatismale et 64,3 pour cent des reclassements.

(4) Les fondeurs formaient une population hétérogène en ce qui concerne la fréquence des symptômes et des absences pour maladie, qui variaient selon les occupations.

(5) Les mouleurs constituaient un groupe spécial qui courait un grand risque de manifestations rhumatismales, surtout de maladie discale.

(6) On ne trouva rien qui puisse indiquer que la forte chaleur radiante dans la fonderie soit capable de réduire la fréquence des symptômes ou des absences pour maladie rhumatismale.

(7) Les facteurs psychologiques qu'on avait étudiés chez ces ouvriers ne semblent avoir aucun rapport avec la fréquence des manifestations rhumatismales, l'absence pour maladie rhumatismale ou l'association du rhumatisme avec d'autres affections.

\section{La frecuencia de manifestaciones reumáticas en fundidores de hierro}

\section{Sumario}

(1) Se investigaron 858 fundidores, desde la edad de 15 años, para determinar la importancia social y económica de manifestaciones reumáticas. Esta investigación forma parte de un estudio más extenso de tales manifestaciones en la industria.

(2) En el curso del año que precedió la entrevista un 42,9 por ciento de ellos habían aquejado síntomas, lo que representa una cifra anticipada.

(3) El dolor lumbar, comprendiendo la enfermedad discal lumbar, fué responsable de un 57 por ciento de las manifestaciones reumáticas, de un 66,3 por ciento de ausencias debidas al reumatismo y de un 64,3 por ciento de los cambios de ocupación debidos al reumatismo.

(4) Los fundidores formaban un población heterogénea respecto a la frecuencia de síntomas y de ausencias de enfermedad, que fueron variables según la ocupación.

(5) Los moldeadores constituían un grupo expuesto a un riesgo especial de manifestaciones reumáticas y de la enfermedad discal en particular.

(6) No se encontraron datos para confirmar la hipótesis de que el calor radiante en la fundición pueda reducir el número de las manifestaciones reumáticas $o$ de las ausencias de trabajo debidas al reumatismo.

(7) Los factores psicológicos que fueron estudiados en estos obreros no parecieron relacionarse de manera alguna con la frecuencia de las manifestaciones reumáticas, las ausencias debidas al reumatismo o la asociación del reumatismo con otras afecciones. 